Article

\title{
Essential Oil of Cymbopogon citratus on the Control of the Curvularia Leaf Spot Disease on Maize
}

\author{
Dalmarcia de Sousa Carlos Mourão, Talita Ferreira de Souza Pereira, Danival José de Souza, \\ Aloísio Freitas Chagas Júnior, Mateus Sunti Dalcin iD, Ronice Alves Veloso, \\ Evelynne Urzêdo Leão and Gil Rodrigues dos Santos* \\ Federal University of Tocantins, Gurupi Campus, 77402-970 Gurupi, Brazil; \\ dalmarciaadm@yahoo.com.br (D.S.C.M.); cupufer@gmail.com (T.F.S.P.); danival@uft.edu.br (D.J.S.); \\ chagasjraf@uft.edu.br (A.F.C.J.); m2d@uft.edu.br (M.S.D.); ronicealves@hotmail.com (R.A.V.); \\ evelynnegpi@hotmail.com (E.U.L.) \\ * Correspondence: gilrsan@uft.edu.br; Tel.: +55-63-3311-3504
}

Academic Editor: Eleni Skaltsa

Received: 13 July 2017; Accepted: 18 August 2017; Published: 20 August 2017

\begin{abstract}
The Curvularia Leaf Spot is becoming more common due to the culture expansion and the low resistance of the cultivated genotypes in tropical regions. Thus, the objective was to evaluate the fungitoxicity of the essential oil of Cymbopogon citratus upon the phytopathogen Curvularia lunata, causative agent of the Curvularia Leaf Spot. There was realized pathogenicity tests of C. lunata in maize plants, phytotoxicity of the essential oil of C. citratus and gas chromatography attached, germination tests of the conidia, and of in vitro inhibition of $C$. lunata. Also, there were realized tests aiming at verifying the phytopathogen control in vivo. In the pathogenicity tests, there were verified symptoms of the disease in all of the suspensions tested on plants. It was observed that the essential oil concentrations of $7.5 \mu \mathrm{L} \mathrm{mL}^{-1}$ to $50 \mu \mathrm{L} \mathrm{mL}^{-1}$ were phytotoxic. The majoritarian chemical components of the essential oil of $C$. citratus were Geranial $(41.46 \%)$ and Neral $(32.43 \%)$. The concentrations of 5 and $7.5 \mu \mathrm{L} \mathrm{mL}^{-1}$ inhibited $100 \%$ of conidia germination. None of the concentrations evaluated effectively inhibited C. lunata mycelial growth in in vitro tests. In the preventive control, the concentration of $7.5 \mu \mathrm{L} \mathrm{mL}^{-1}$ was sufficient for the reduction of the progress of the disease, however the curative control was not efficient on the tested dosages.
\end{abstract}

Keywords: botanical fungicide; lemongrass; Zea mays; preventive control; curative control

\section{Introduction}

Even Brazil, occupying a highlighting position between the biggest world's producers, has a productivity that is considered low when compared to other producer countries. In the state of Tocantins, it is observed expressive increases of planted areas and of productivity on maize culture, which have been higher than the national mean in the last years. These indicators make the state of Tocantins one of the greatest producers of the North region [1], and one of the potential producers of grains of Brazil in a near future [2].

Among the factors that affect the productivity and the quality of the grain, there are the diseases. Recent studies show an increase on the frequency of the fungus Curvularia lunata (Wakker) provoking diseases in maize cultivars in China [3]. In maize plantations in Brazil, there are few records of the Curvularia Leaf Spot in scientific literature. In the state of Tocantins there is an observed marked increase on the incidence of this disease for many years [4]. In a disease survey on Tocantins realized by [5], the Curvularia Leaf Spot was noted together with helmintosporiosis (H. turcicum) as more incident.

Nowadays, alternatives for reduction of the use of pesticides are searched, and some works have already been realized aiming at identifying new bioproducts based on medicinal plants with 
antimicrobial action [6]. Some works have already showed that the addition of essential oils in specific concentrations on the culture environments with phytopathogenic fungi is efficient in the inhibition of development of these organisms [7-10].

Considering the lack of works developed for the control of Curvularia Leaf Spot in the state of Tocantins and in Brazil, studies are necessary in pursuing the disease management. The objective of the present work was to evaluate the fungitoxicity of the essential oil of C. citratus, commonly known as lemongrass, upon the phytopathogen C. lunata, and also to verify its efficiency on the preventive and curative control of Curvularia Leaf Spot on maize.

\section{Material and Methods}

The experiments were performed at the Phytopathology Laboratory of the Gurupi Campus, Federal University of Tocantins (UFT), in the state of Tocantins, Brazil. C. lunata was initially isolated from the maize leaves derived from the experimental field of UFT with the diseases' symptoms, and put in a PDA (Potato, Dextrose, Agar) culture environment.

\subsection{Essential Oil Attainment}

For the extraction of the oil of C. citratus (DC.) Stapf, de Candolle and reclassified by Otto Stapf, the hydrodistillation method was used, utilizing the Clevenger device modified in accordance with the methodology described by [11].

\subsection{Pathogenicity of the Isolates of Curvularia Lunata to Maize Plants}

The pathogenicity of the fungus C. lunata was verified through inoculation tests in maize plants. Initially, the seeds of the Traktor (Syngenta ${ }^{\circledR}$ ) maize were sowed in seven polyethylene vases ( $3 \mathrm{~L}$ capacity) containing substrate, improved with $10 \mathrm{~g}$ of commercial fertilizer NPK (5-25-15) in each vase. There were made three holes, with two seeds added in each. The pruning was necessary when the plants reached two pairs of definitive leaves, which was in approximately 15 days, and then the inoculation could be initiated. There was utilized an entirely casualized design with seven treatments and three repetitions. There were different tested concentrations of conidia, being $10^{1}, 10^{2}$, $10^{3}, 10^{4}, 10^{5}$, and $10^{6}$ conidia $\mathrm{mL}^{-1}$, the concentrations were adjusted with the aid of a Neubauer chamber. The positive control prepared utilized only distilled water with the same volume utilized for the concentrations of the conidia. For the inoculation there was utilized a manual sprayer $(500 \mathrm{~mL}$ capacity) containing suspension of conidia of C. lunata derived from cultures incubated for 10 days in BOD (Biochemical Oxygen Demand) at $25^{\circ} \mathrm{C}$. The suspensions were applied until the runoff point on the leaves $(10 \mathrm{~mL})$. Following this, the vases were kept for $48 \mathrm{~h}$ with humid cotton and closed with plastic bags aiming at providing the humid chamber. From $48 \mathrm{~h}$ after the inoculation, the vases were left in a shaded place until the appearance of the first leaf symptoms of the Curvularia Leaf Spot. When the symptoms were visualized on the inoculated tissue, the fungus was re-isolated and cultivated in PDA environment. Afterwards, the fungus was inoculated again and re-isolated in the PDA environment, aiming at the compliance of all the stages of the Koch's postulates.

\subsection{Preparation of the Solutions for Biological Activity}

For the preparation of the essential oil solutions sterilized small glass jars with lids were utilized in order to receive the different concentrations. One supply solution was prepared for the higher concentration utilizing a volumetric flask of $10 \mathrm{~mL}$. On sequence, there was added initially the oil and adjusted the concentration of $50 \mu \mathrm{L} \mathrm{mL}^{-1}$ to a volume of $10 \mathrm{~mL}$, next there was added Tween 80 (1 oil: 1 Tween). In laminar flow chamber, the flask was softly agitated and next was inserted the distilled water. After the agitation, there was obtained a homogeneous mixture. Subsequently, there were realized the other dilutions until the concentrations of $2.5 \mu \mathrm{L} \mathrm{mL}^{-1}, 5 \mu \mathrm{L} \mathrm{mL}^{-1}$ and $7.5 \mu \mathrm{L} \mathrm{mL}^{-1}$ were obtained. As negative and positive control there were prepared the solutions of methyl-thiophanate $\left(2 \mathrm{mg} \mathrm{mL}^{-1}\right)$ and sterilized distilled water, respectively. 


\subsection{Phytoxicity of the Essential Oil (Cymbopogon citratus) to Maize Plants}

The phytoxicity test was realized in greenhouse conditions. There were utilized six polyethylene vases filled with half commercial substrate and half soil. There was added $10 \mathrm{~g}$ of fertilizer NPK (5-25-15) in each vase. On the maize plantation there were utilized Traktor (Syngenta ${ }^{\circledR}$ ) seeds, sowing two for each hole. After sowing, the vases were irrigated daily until the seedlings growth reached four definitive leaves, or 15 days after plantation. Manual sprayers were used for the application of the treatments. There was utilized an entirely casualized design with six treatments and three repetitions, where different concentrations of the $C$. citratus oil were tested, being: $2.5 \mu \mathrm{L} \mathrm{mL}^{-1}, 5 \mu \mathrm{L} \mathrm{mL}^{-1}$, $7.5 \mu \mathrm{L} \mathrm{mL}^{-1}, 10 \mu \mathrm{L} \mathrm{mL}^{-1}, 50 \mu \mathrm{L} \mathrm{mL}^{-1}$. The positive control was prepared utilizing only distilled water with the same volume utilized for the concentrations of the oil. Each vase was pulverized with $5 \mathrm{~mL}$ of the solutions. The evaluation was made according to the phytotoxicity scale adapted from [12] until the tenth day.

\subsection{In Vitro Inhibiton of Curvularia lunata}

Aiming at verifying the effect of essential oil upon the mycelial growth of the phytopatogen, there was different concentrations of $C$. citratus oil were tested, being: $2.5 \mu \mathrm{L} \mathrm{mL}^{-1}, 5 \mu \mathrm{L} \mathrm{mL}^{-1}, 7.5 \mu \mathrm{L} \mathrm{mL}^{-1}$, $10 \mu \mathrm{L} \mathrm{mL}^{-1}$ and $50 \mu \mathrm{L} \mathrm{mL}^{-1}$. As negative and positive control there were prepared the solutions of methyl-thiophanate $\left(2 \mathrm{mg} \mathrm{mL}^{-1}\right)$ (one for C. lunata and the other for Fusarium sp.) and sterilized distilled water, respectively. There was tested another pathogen in order to verify the efficiency of the proposed fungicide. There was utilized $100 \mu \mathrm{L}$ from each concentration, distributed on the surface of the culture environment with the aid of a Drigalski spatula. Next, a mycelium-agar disk with $6 \mathrm{~mm}$ diameter was put into the center of the plates. The plates were sealed with PVC (Polyvinyl chloride) film, identified and incubated in BOD at $25^{\circ} \mathrm{C}$ for 10 days. The evaluations were realized with digital caliper assessing the mycelial diameter of the fungus tracing two orthogonal axes with each other upon the center of the plates resulting in a arithmetic mean and measured every two days $(2,4,6,8$ and 10 days).

\subsection{Inhibitory Effect to the Germination of Conidia of Curvularia lunata}

For the evaluation of the inhibition effect of the C. citratus essential oil upon the germination of conidia there was used an entirely casualized design, with seven treatments and three repetitions. The treatments were constituted by the following oil concentrations: $0.625 ; 1.25 ; 2.5 ; 5.0$, and $7.5 \mu \mathrm{L} \mathrm{mL} \mathrm{L}^{-1}$, negative control, with methyl-thiophanate $\left(2 \mathrm{mg} \mathrm{mL}^{-1}\right)$ and positive control with distilled/sterilized water. From each oil treatment, there was mixed $100 \mu \mathrm{L}$ of the oil concentrations and $100 \mu \mathrm{L}$ of the $C$. lunata conidia concentration $\left(10^{4}\right.$ conidia $\left.\mathrm{mL}^{-1}\right)$. The evaluation was made $12 \mathrm{~h}$ after the inoculation in optical microscope.

The plates containing the oil solutions were incubated on a humid chamber (trays) at $27{ }^{\circ} \mathrm{C}$ for $12 \mathrm{~h}$. After this period the evaluation was made with approximately 200 conidia where they were counted, and the percentage of germination of conidia of inhibition were calculated, adapted from $[13,14]$.

\subsection{Chromatographic Analyses of the Essential Oil of Lemongrass}

The qualitative and quantitative analyses of the essential oils were realized by chromatography in gas phase, attached to the mass spectrometry CG-MS. The chromatograph utilized was the model Shimadzu GC-210, equipped with mass selective detector model QP2010 Plus, and was operated in these conditions: capillary column of fused silica TRX-5MS (30 m $\times 0.25 \mathrm{~mm} \times 0.25 \mu \mathrm{m}$ of film thickness); with the following programming of the temperature on the column: $60-240{ }^{\circ} \mathrm{C}\left(3{ }^{\circ} \mathrm{C} \mathrm{min}-1\right)$; injector temperature: $220^{\circ} \mathrm{C}$; carrier gas helium; and, splitless injection with injected volume of $1 \mu \mathrm{L}$ of a solution 1:1000 in hexane. For the mass spectrometer (MS), there were utilized the following conditions: impact energy of $70 \mathrm{eV}$; ion source, and interface temperature: $200{ }^{\circ} \mathrm{C}$. There was injected, 
at the sample conditions, a homologous series of $n$-alkanes $\left(\mathrm{C}_{9} \mathrm{H}_{20} \ldots \mathrm{C}_{26} \mathrm{H}_{54}\right)$. The obtained specters were compared with the Nist and Wiley 229 Library's database and the retention rate calculated to each component was compared to the tabulated, according to [15]. The quantification of essential oils compounds levels were obtained with a gas chromatograph equipped with a flame ionization detector (FIT) using a Shimadzu GC-210 device, in the following methodology: capillary column RTX-5MS $\left(30 \mathrm{~m} \times 0.25 \mathrm{~mm} \times 0.25 \mu \mathrm{m}\right.$ of film thickness); injector temperature: $220{ }^{\circ} \mathrm{C}$; FIT temperature: $300{ }^{\circ} \mathrm{C}$; with column programming: initial temperature of $60^{\circ} \mathrm{C}$ with a heating rate of $3{ }^{\circ} \mathrm{C} \mathrm{min}{ }^{-1}$ until $240{ }^{\circ} \mathrm{C}$, next, passing to a heating rate of $10^{\circ} \mathrm{C} \mathrm{min}^{-1}$ until $300{ }^{\circ} \mathrm{C}$, remaining on this temperature for $10 \mathrm{~min}$; drag gas nitrogen $\left(1.18 \mathrm{~mL} \mathrm{~min}^{-1}\right)$; split rate 1:50; column pressure of $115 \mathrm{KPa}$, and injected volume of $1 \mu \mathrm{L}$ in hexane.

\subsection{Curative and Preventive Control of Curvularia Leaf Spot on Maize}

There were used plates containing inoculum of seven days of incubation where were added $10 \mathrm{~mL}$ of sterilized distilled water for the preparation of the conidia solutions. Utilizing a soft brush, there was realized the detachment of the conidia. This solution was filtered in gauze, and the conidia were counted in the Neubauer chamber. The concentration of $10^{4}$ conidia $\mathrm{mL}^{-1}$ was utilized for the biological activities. Following, the vases were kept for $48 \mathrm{~h}$ with humid cotton and closed with a plastic bag in order to provide a humid chamber. $48 \mathrm{~h}$ after the inoculation, the vases were left in shaded place until the appearance of the first leaf symptoms of Curvularia Leaf Spot. For the evaluation of the severity of the diseases, there was used a notes scale according to [16], where $0=$ healthy plant; $1=$ less than $1 \%$ of leaf area sick; $3=1$ to $5 \%$ of the leaf area sick; $5=6$ to $25 \%$ of the leaf area sick; $7=26$ to $50 \%$ of the leaf area sick; and, $9=$ more than $50 \%$ of the leaf area sick.

In order to evaluate the preventive effect of the essential oil, an entirely casualized design was used, where different concentrations of the $C$. citratus oil were tested, being: $0.625 ; 1.25 ; 2.5 ; 5.0$; and $7.5 \mathrm{mg} \mathrm{mL}^{-1}$, and three repetitions. As control, there were utilized water-pulverized plants (positive control) and methyl-thiophanate-pulverized plants at $2 \mathrm{mg} \mathrm{mL}^{-1}$ (negative control). From each treatment, $5 \mathrm{~mL}$ was sprayed on the plants and one hour after, the plants were inoculated with $5 \mathrm{~mL}$ of the conidia solution $\left(10^{4}\right.$ conidia $\left.\mathrm{mL}^{-1}\right)$ of $C$. lunata. The evaluation of the severity of the disease was made every two days after inoculation (5 evaluations on total).

For evaluating the curative effect of the essential oil, an entirely casualized design was used, where different concentrations of the $C$. citratus oil were tested, being: $0.625 ; 1.25 ; 2.5 ; 5.0$; and $7.5 \mu \mathrm{L} \mathrm{mL}^{-1}$, and three repetitions. As a control, there were utilized water-pulverized plants (positive control) and methyl-thiophanate-pulverized plants at $2 \mathrm{mg} \mathrm{mL}^{-1}$ (negative control). The maize plants were inoculated with $5 \mathrm{~mL}$ of the conidia solution $\left(10^{4}\right.$ conidia $\left.\mathrm{mL}^{-1}\right)$ of $C$. lunata, and next the vases were kept for $48 \mathrm{~h}$ with humid cotton and closed with plastic bag in order to provide a humid chamber. $48 \mathrm{~h}$ after the inoculation, the plants were left in shaded place until the appearance of the first leaf symptoms of Curvularia Leaf Spot. From each treatment, $5 \mathrm{~mL}$ of the already cited oil concentrations was sprayed on the plants after verification of the appearance of the disease, and the evaluation of severity of the disease was made every two days, being realized a total of five evaluations after the application of the oil solutions. With the obtained results in the evaluations, the Area Under Disease Progress Curve (AUDPC) was calculated, according to [17].

\section{Results}

The pathogenicity of the C. lunata isolates in maize plants was confirmed, in which typical symptoms were small circular spots on the verified leaves after the incubation period of $48 \mathrm{~h}$ later than the inoculation on the plants. However, all the conidia suspensions provoked injuries on the leaves of maize plants (Figure 1). Among the six conidia concentrations prepared $\left(10^{1}, 10^{2}, 10^{3}, 10^{4}, 10^{5}\right.$, and $10^{6}$ conidia $\left.\mathrm{mL}^{-1}\right)$, there was a incidence gradient of leaf spots from the lower concentration to the higher concentration of $10^{4}$ conidia $\mathrm{mL}^{-1}$. The concentration of $10^{4}$ conidia $\mathrm{mL}^{-1}$ was the chosen 
for the realization of the preventive and curative tests of the next stages realized, due to the better simulation of the severity of the disease verified under favorable conditions to the disease on the field.

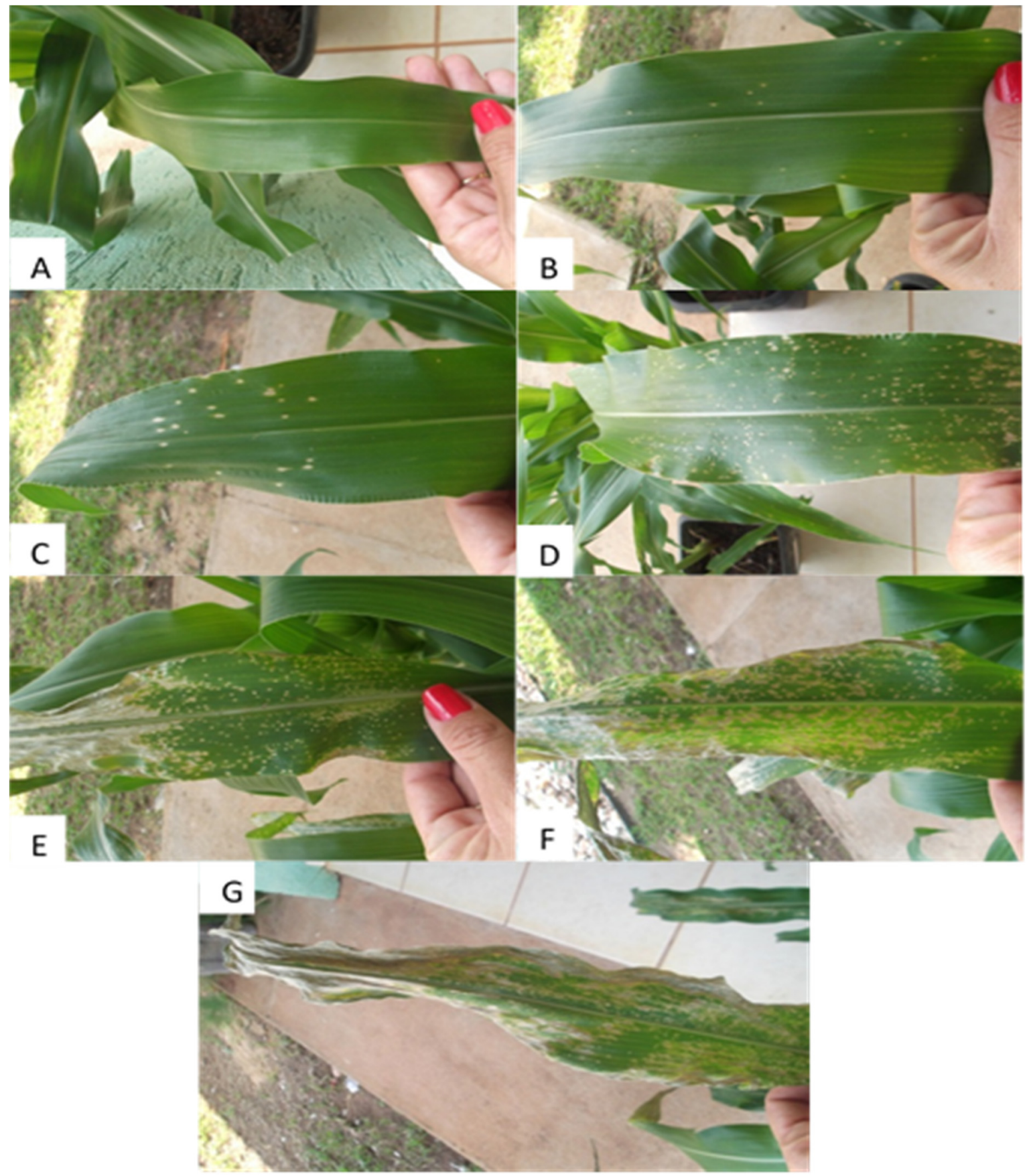

Figure 1. Severity of the Curvularia Leaf Spot disease in maize plants, submitted to the inoculation with different conidia concentrations of Curvularia lunata. (A-Control; B-10 $0^{1}$ conidia $\mathrm{mL}^{-1}$; C $-10^{2}$ conidia $\mathrm{mL}^{-1} ; \mathbf{D}-10^{3}$ conidia $\mathrm{mL}^{-1} ; \mathrm{E}-10^{4}$ conidia $\mathrm{mL}^{-1} ; \mathbf{F}-10^{5}$ conidia $\mathrm{mL}^{-1}$; $\mathrm{G}-10^{6}$ conidia $\left.\mathrm{mL}^{-1}\right)$.

In the phytotoxicity essay, the non-toxic concentrations were applied in the in vivo tests. Phytotoxicity symptoms appeared after $12 \mathrm{~h}$ of the application on leaves. It was verified that at the end of 10 days there was phytotoxicity in the concentrations of $7.5 \mu \mathrm{L} \mathrm{mL}^{-1}(5.8 \%), 10 \mu \mathrm{L} \mathrm{mL}^{-1}$ $(18.1 \%)$, and $50 \mu \mathrm{L} \mathrm{mL}^{-1}(20.9 \%)$, thus showing that cannot be utilized in tests of control of the disease 
in the plant, provoking leaf necrosis, followed by posterior wilt. Yet the concentrations $2.5 \mu \mathrm{L} \mathrm{mL}-1$ and $5.0 \mu \mathrm{L} \mathrm{mL}^{-1}$ did not provoke phytotoxicity along the evaluation (Figure 2).

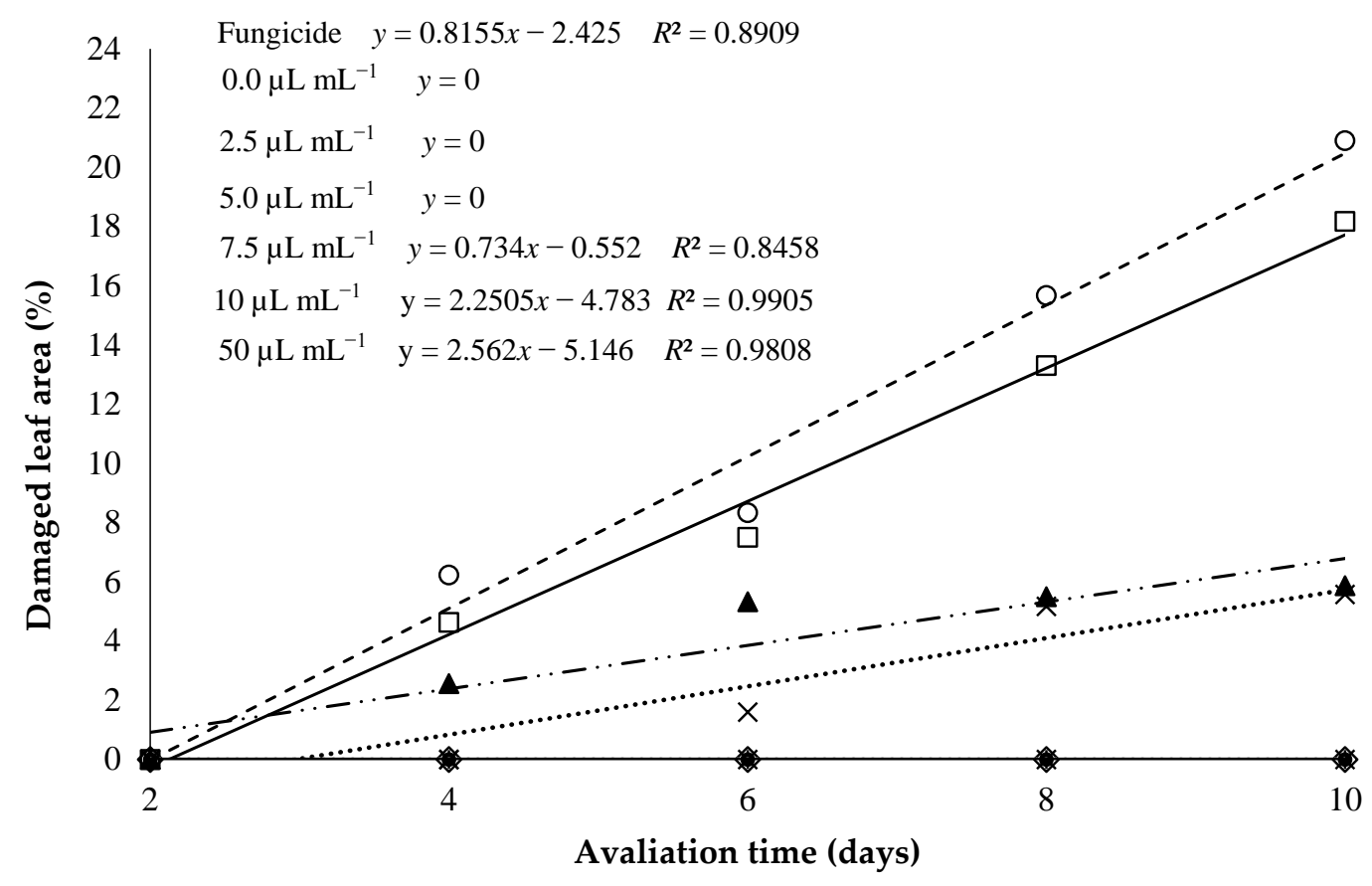

$\times$ Fungicide $* 0,0 \bullet 2,5 \diamond 5,0 \Delta 7,5 \square 10050$

Figure 2. Phytotoxicity (Damaged leaf area $x$ Incubation days) of different $C$. citratus essential oil concentrations in maize plants. Treatments $\left(2.5 \mu \mathrm{L} \mathrm{mL}^{-1}, 5 \mu \mathrm{L} \mathrm{mL}^{-1}, 7.5 \mu \mathrm{L} \mathrm{mL}^{-1}, 10 \mu \mathrm{L} \mathrm{mL}^{-1}\right.$, and $50 \mu \mathrm{L} \mathrm{mL}^{-1}$ ) positive control (distilled water), negative control—(fungicide—methyl-thiophanate $2 \mathrm{mg} \mathrm{mL}^{-1}$ ).

In the effect of the in vitro inhibition of the C. citratus essential oil upon C. lunata, it was verified the growth of the phytopathogen in all the tested concentrations (Table 1). Regarding the concentration of $50 \mu \mathrm{L} \mathrm{mL}{ }^{-1}$, the growth was partially inhibited, with values lower than the control values.

Table 1. Mean mycelial diameter ( $\mathrm{mm}$ ) of Curvularia lunata under different concentrations of the C. citratus essential oil.

\begin{tabular}{|c|c|c|c|c|c|c|c|}
\hline \multirow[t]{2}{*}{ Treatments } & \multicolumn{5}{|c|}{ Avaliation Time (Incubation Days) } & \multirow[t]{2}{*}{ Regression Equation } & \multirow[t]{2}{*}{$\mathbf{R}^{2}$} \\
\hline & 2 & 4 & 6 & 8 & 10 & & \\
\hline PC & 26.21 & 44.69 & 59.44 & 68.96 & 80.56 & $y=13.297 x+16.081$ & 0.98 \\
\hline $\mathrm{NC}^{\mathrm{a}}$ & 25.27 & 42.51 & 59.44 & 67.4 & 78.11 & $y=13.057 x+15.375$ & 0.97 \\
\hline $\mathrm{NC}^{\mathrm{b}}$ & 8.59 & 9.14 & 9.74 & 9.94 & 10.51 & $y=0.464 x+8.192$ & 0.98 \\
\hline $\mathrm{C}_{1}$ & 25.06 & 40.90 & 55.12 & 69.72 & 82.89 & $y=14.448 x+11.394$ & 0.99 \\
\hline $\mathrm{C}_{2}$ & 24.36 & 40.22 & 53.31 & 69.05 & 82.62 & $y=14.535 x+10.307$ & 0.99 \\
\hline $\mathrm{C}_{3}$ & 21.4 & 36.27 & 52.35 & 68.29 & 82.36 & $y=15.394 x+5.952$ & 0.99 \\
\hline $\mathrm{C}_{4}$ & 19.97 & 36.08 & 51.96 & 66.74 & 81.35 & $y=15.342 x+5.194$ & 0.99 \\
\hline $\mathrm{C}_{5}$ & 18.09 & 35.54 & 50.74 & 66.61 & 77.37 & $y=14.963 x+4.781$ & 0.99 \\
\hline
\end{tabular}

PC: Positive control (distilled water), $\mathrm{NC}^{\mathrm{a}}{ }^{\mathrm{a}}$ : Negative control 1 (methyl-thiophanate under Curvularia), NC ${ }^{\mathrm{b}}$ : Negative control 2 (methyl-thiophanate under Fusarium sp.), $C_{1}-C_{5}$ : Concentrations in $\mu \mathrm{L} \mathrm{mL}^{-1}\left(C_{1}=2.5 \mu \mathrm{L} \mathrm{mL}^{-1}\right.$, $\mathrm{C}_{2}=5 \mu \mathrm{L} \mathrm{mL}^{-1}, \mathrm{C}_{3}=7.5 \mu \mathrm{L} \mathrm{mL}^{-1}, \mathrm{C}_{4}=10 \mu \mathrm{L} \mathrm{mL}^{-1}$ and $\left.\mathrm{C}_{5}=50 \mu \mathrm{L} \mathrm{mL}^{-1}\right)$.

Compared the mycelial growth means of the pathogen on the 10th day of incubation, it was verified that the $C$. citratus essential oil did not provide an inhibitory effect among the concentrations of $2.5 \mu \mathrm{L} \mathrm{mL}^{-1}$ (Table 1). Thus, on these concentrations, the phytopathogen mycelium grew normally 
along the days, and only in the concentrations of $50 \mu \mathrm{L} \mathrm{mL}^{-1}$ (C5) was the partial inhibitory effect observed (Table 1).

For the C. lunata phytopathogen, the negative control (methyl-thiophanate) did not present a relevant difference from the positive control (water), even with the utilization of the concentration above the recommended dosage. Thus, not efficiency in the mycelial growth inhibition of this pathogen in vitro was observed. On the other side, it was verified mycelial inhibition of the Fusarium genre when submitted to the same fungicide (negative control 2), and in the same concentration.

On the essay of C. lunata conidia germination inhibition, it was verified that it had $100 \%$ of conidia germination on the positive control (methyl-thiophanate). The concentrations of 5.0 and $7.5 \mu \mathrm{L} \mathrm{mL}^{-1}$ of the C. citratus oil also totally inhibited the conidia germination (Figure 3). Yet the concentrations $0.625 ; 1.25$ and $2.5 \mu \mathrm{L} \mathrm{mL}^{-1}$ had a low inhibition percentage of $3.3 \%, 2.3 \%$, and $25 \%$, respectively, indicating oil activity upon the conidia, even in the lower concentrations.

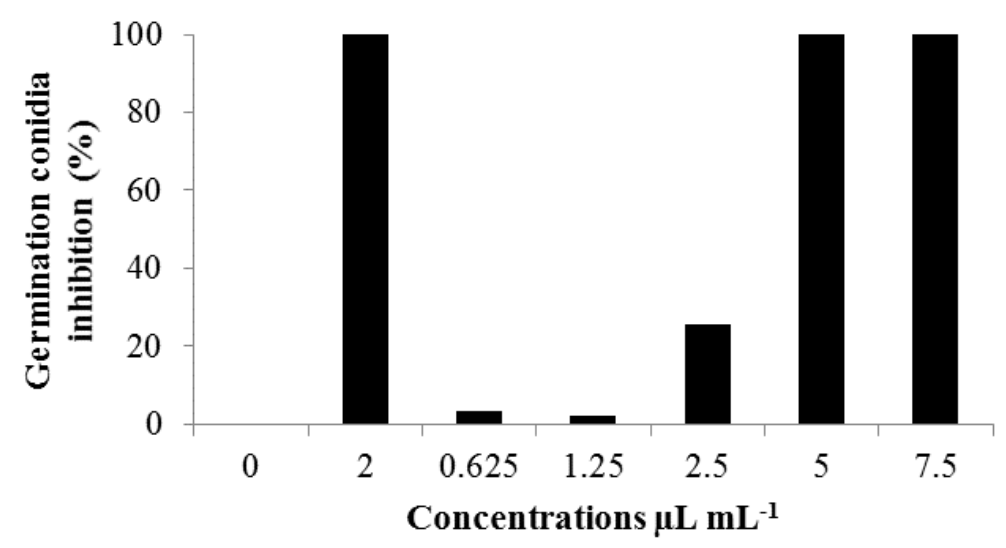

Figure 3. Conidia germination inhibition of Curvularia lunata under crescent dosages of $C$. citratus (Cymbopogon citratus) essential oil. Treatments: $0\left(0.0 \mu \mathrm{L} \mathrm{mL} \mathrm{L}^{-1}\right), 2$ (Negative control, with methyl-thiophanate $2 \mathrm{mg} \mathrm{mL}^{-1}$ ). Concentrations of $C$. citratus essential oil $=0.625 \mu \mathrm{L} \mathrm{mL}^{-1}$; $1.25 \mu \mathrm{L} \mathrm{mL}^{-1} ; 2.5 \mu \mathrm{L} \mathrm{mL}^{-1} ; 5 \mu \mathrm{L} \mathrm{mL}^{-1}$ and $7.5 \mu \mathrm{L} \mathrm{mL}^{-1}$ ).

It can be observed (Table 2) that the majoritarian chemical components present on the essential oil of Cymbopogon citratus leaves were Geranial (41.46\%) and Neral (32.43\%).

Table 2. Chemical components of the Cymbopogon citratus essential oil identified by mass spectrometry (CG/MS) and its respective levels expressed in percentage.

\begin{tabular}{cccc}
\hline \multicolumn{4}{c}{ Lemongrass Essential Oil } \\
\hline Constituints & RT & IR & $(\%)$ \\
Mircene & 7.742 & 986 & 9.73 \\
(Z)- $\beta$-oxime & 9.344 & 1020 & 0.32 \\
(E)- $\beta$-oxime & 9.753 & 1029 & 0.16 \\
Linalool & 11.845 & 1074 & 1.64 \\
Neral & 17.885 & 1209 & 32.43 \\
Geraniol & 18.375 & 1220 & 4.52 \\
Geranial & 19.233 & 1239 & 41.46 \\
2-undecanone & 20.099 & 1359 & 0.35 \\
Geranyl acetate & 23.737 & 1443 & 0.42 \\
E-Caryofylene & 31.997 & 1641 & 0.17 \\
Anothers & - & - & 8.8 \\
Total & - & - & 100 \\
\hline
\end{tabular}

$\mathrm{RT}=$ retention time; $\mathrm{IR}=$ calculated retention rate. 
In the preventive and curative effects, the utilized concentrations were different from the tested in vitro (fungitoxicity) and in vivo (phytotoxicity), because from the concentration $7.5 \mu \mathrm{L} \mathrm{mL} \mathrm{L}^{-1}$, the plants presented phytotoxicity symptoms. Therefore, there were tested concentrations below the utilized in in vitro tests.

For the preventive effect of the C. citratus essential oil under progress of the Curvularia Leaf Spot disease (Figure 4), it was observed a greater Area Under Disease Progress Curve (AUDPC) in the positive control (Distilled water), in relation to the other treatments. For the plants treated with the fungicide methyl-thiophanate (6) there was reduction on the disease symptoms in relation to most of the utilized treatments. However, in the oil concentration $7.5 \mu \mathrm{L} \mathrm{mL}^{-1}$ a similar effect to the control with methyl-thiophanate was verified. The other concentrations had similar AUDPC.

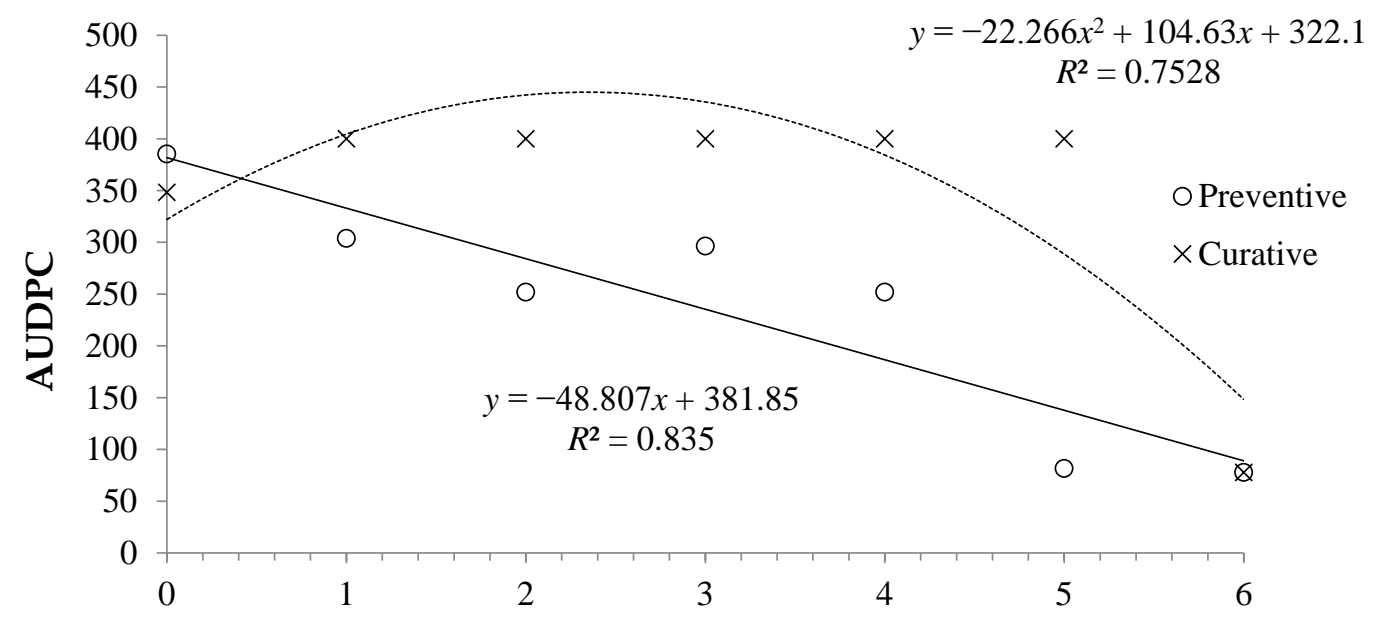

Lemongrass essential oil concentration $\left(\mu \mathrm{L} \mathrm{mL}^{-1}\right)$

Figure 4. Area Under Disease Progress Curve (AUDPC) for preventive and curative in vivo under positive control with water $\left(0=0.0 \mu \mathrm{L} \mathrm{mL}^{-1}\right)$ and negative control with methyl-thiophanate $\left(6=2.0 \mathrm{mg} \mathrm{mL}{ }^{-1}\right)$, with five different concentrations $\left(1=0.625 \mu \mathrm{L} \mathrm{mL}^{-1}, 2=1.25 \mu \mathrm{L} \mathrm{mL}^{-1}\right.$, $3=2.5 \mu \mathrm{L} \mathrm{mL}^{-1}, 4=5 \mu \mathrm{L} \mathrm{mL}^{-1}$, and $5=7.5 \mu \mathrm{L} \mathrm{mL}^{-1}$ ) of the Cymbopogon citratus essential oil.

Regarding the curative control (Figure 4), it was observed that the application of C. citratus essential oil did not provide the expected effect and there was no control of the disease on the symptomatic plants and the treatments AUDPC was similar to the control. Yet the treatment with methyl-thiophanate was also efficient on the curative control of the disease.

\section{Discussion}

The phytoxicity on maize plants has as a principal symptom the appearance of necrosis on the leaves, specifically on the regions in which the solution accumulates, like borders and leaf veins, causing a loss of the green leaf area [18]. Studies realized by [19], show that the concentration of $1 \%$ of the $C$. citratus oil showed presented low toxicity $(\leq 25 \%)$, since the plants presented only a light necrosis on the leaves.

The C. citratus essential oil has as majoritarian component the Citral, with $69.31 \%$ (Geranial + Neral) and the Myrcene, with 23.77\%, both being monoterpenes, according to [20] studies, showing that both the oil and its majoritarian component, the Citral, acted on the mycelial inhibiton of the phytopathogens Fusarium oxysporum cubense, Colletotrichum gloeosporioides, Bipolaris sp. and Alternaria alternata.

When observing the fungistatic action in vitro, [10] noted that the lemongrass (C. citratus) essential oil inhibited the development of the fungi Didymella, bryoniae, pyricularia grisea, Rizoctonia solani and Sclerotium rolfsii, demonstrating the high potential for the alternative control of these pathogens. 
Studies realized by [21] obtained the total inhibition of the mycelial growth and of the germination of spores from Colletotrichum gloeosporioides utilizing the C. citratus essential oil from the concentration of $1 \mu \mathrm{L} \mathrm{mL}{ }^{-1}$.

The chemical composition of the C. citratus essential oil is described in many studies. Elevated levels of Geranial and Neral in the chemical composition of lemongrass were observed by [22], with a mean of approximately $51 \%$ and $36 \%$, respectively. The authors [23] also observed similar percentages for Geranial (46.3\%) and Neral (31.28\%). Yet [24] found levels of 43.6\% for Neral and 34\% for Geranial, values that are different to the ones found on this work, where the highest percentage was of Neral. It is known that many factors, such as extraction method, access and conditions of cultivation may have an influence on the levels of the essential oil components. That can explain the differences found in the present study.

There is no record in the scientific literature about the preventive and curative effect in vivo of any essential oil upon the Curvularia Leaf Spot disease. Nevertheless, [25] when studying another pathosystem, it demonstrated good results for the alternative control. Five treatments were tested with lemongrass and other essential oils against the helmintosporiosis of Tanzania grass (Panicum maximum Jacq.) in preventive and curative effect.

It was verified by [19], on the control of the phytopathogen Colletotrichum graminicola, that the lemongrass essential oil stood out as the most fungitoxic, since that occurred inhibition of $100 \%$ of fungus mycelial growth from the concentration $\left(0.50 \mu \mathrm{L} \mathrm{mL}^{-1}\right)$. The fact that the C. citratus essential oil was not efficient on the in vitro inhibition test, but effective on the conidia germination and preventive control, demonstrates that it is very important to realize essays in vivo, but is also necessary in future works, in order to enlighten the mechanism of action of essential oils upon the plant diseases.

\section{Conclusions}

The Curvularia lunata isolate is pathogenic to the maize plants on the tested concentrations. For the phytotoxicity essay the concentration above $7.5 \mu \mathrm{L} \mathrm{mL}{ }^{-1}$ was phytotoxic to the plants, marking off the maximum concentration to be utilized. The C. lunata phytopathogen showed itself resistant to the methyl-thiophanate in a concentration applied above the recommended in in vitro tests. In the in vitro control the tested dosages of $C$. citratus essential oil presented promising results and can be a great alternative on the management of this disease, however the curative application was not efficient.

Author Contributions: Conceived and designed the experiments: D.S.C.M., G.R.S., A.F.C.J. and D.J.S. Conducted the bioassays: D.S.C.M., R.A.V., T.P.S.F. Interpretation of results: D.S.C.M., G.R.S., M.S.D., E.U.L. Contributed to writing of the manuscript: D.S.C.M., G.R.S., M.S.D., T.P.S.F.

Conflicts of Interest: The authors declare no conflict of interest.

\section{References}

1. CONAB. Companhia Nacional de Abastecimento. Accompaniment of Brazilian Crop: Grains: Crop 2014/2015: Eighth Survey, May/2015. 2015; p. 118. Available online: http:/ /www.conab.gov.br/OlalaCMS/ uploads/arquivos/15_05_13_08_46_55_boletim_graos_maio_2015.pdf (accessed on 20 November 2015).

2. Chagas, J.F.R.; Santos, G.R.; Costa, R.V.; Costa, L.V.; Silva, D.D.; Simon, J.; Mourão, D.S.C. Diseases principal of maize in the State of Tocantins. Circ. Téc. Embrapa 2015, 213, 1-13. Available online: http:/ / www.infoteca. cnptia.embrapa.br/handle/doc/1038372 (accessed on 15 November 2015).

3. Gao, S.; Liu, T.; Li, Y.; Wu, Q.; Fu, K.; Chen, J. Understanding resistant germplasm-induced virulence variation through analysis of proteomics and suppression subtractive hybridization in a maize pathogen Curvularia lunata. Proteomics 2012, 12, 3524-3535. [CrossRef] [PubMed]

4. Vaz-De-Melo, A.; Afférri, F.S.; Dotto, M.A.; Peluzio, J.M.; Santos, G.R.; Carvalho, E.V. Maize hybreds reaction to Curvularia ssp., under two levels of nitrogen fertilization, in the south Tocantins State, Brazil. Sci. Agrar. 2010, 11, 149-154. [CrossRef] 
5. Carvalho, E.V.; Afférri, F.S.; Peluzio, J.M.; Dotto, M.A.; Cappellesso, R.B.; Melo, A.V. Agronomic performance and genetic divergence in the selection of strains of maize S5. Biosci. J. 2011, 27, 794-797. Available online: http://www.seer.ufu.br/index.php/biosciencejournal/article/view/11243/7893 (accessed on 15 November 2015).

6. Muthaiyan, A.; Martin, E.M.; Natesan, S.; Crandall, P.G.; Wilkinson, B.J.; Ricke, S.C. Antimicrobial effect and mode of action of terpeneless cold-pressed Valencia orange essential oil on methicillin-resistant Staphylococcus aureus. J. Appl. Microbiol. 2012. [CrossRef] [PubMed]

7. Diniz, S.P.S.S.; Coelho, J.S.; Rosa, G.S.; Specian, V.; Oliveira, R.C.; Oliveira, R.R. Bioactivity of Mentha arvensis L. essential oil in phytopathogenic fungi control. Rev. Bras. Plantas Med. 2008, 10, 9-11. Available online: http:/ / www.sbpmed.org.br/download/issn_08_4/artigo2_p9-11.pdf (accessed on 14 November 2015).

8. Silva, A.C.; Sales, N.L.P.; Araújo, A.V.; Caldeira Júnior, C.F. In vitro effect of plant compounds on the fungus Colletotrichum gloeosporioides Penz. isolated from passion fruit. Ciênc. Agrotecnol. 2009, 33, 1853-1860. [CrossRef]

9. Scapin, C.R.; Carnelossi, P.R.; Vieira, R.A.; Schwan-Estrada, K.R.F.; Cruz, M.E.S. In vitro fungitoxicity of plant extracts on Exserohilum turcicum (Pass) Leonard \& Suggs. Rev. Bras. Plantas Med. 2010, 12, 57-61. [CrossRef]

10. Sarmento-Brum, R.; Castro, H.; Silva, M.; Sarmento, R.; Nascimento, I.; Santos, G.R. Vegetable oils effect on the inhibition of mycelial growth of phytopathogenic fungi. J. Biotech. Biodivers. 2014, 5, 63-70. Available online: https:/ / sistemas.uft.edu.br/periodicos/index.php/JBB/article/view/732 (accessed on 10 November 2015).

11. Guimarães, L.G.L.; Cardoso, M.G.; Zacaroni, L.M.; Lima, R.K. Influence of light and temperature on the oxidation of the essential oil of lemongrass (Cymbopogon Citratus (D.C.) Stapf). Quim. Nov. 2008, 31, 1476-1480. [CrossRef]

12. Freitas, S.P.; Moreira, J.G.; Freitas, I.L.J.; Freitas Júnior, S.P.; Amaral Júnior, A.T.; Silva, V.Q.R. Phytotoxicity of herbicides to different popcorn cultivars. Planta Daninha 2009, 27, 1095-1103. [CrossRef]

13. Aguiar, R.W.S.; Ootani, M.A.; Ascencio, S.; Ferreira, T.P.S.; Santos, M.M.; Santos, G.R. Fumigant Antifungal Activity of Corymbia citriodora and Cymbopogon nardus Essential Oils and Citronellal against Three Fungal Species. Sci. World J. 2014, 1-8. [CrossRef]

14. Balbi-Peña, M.I.; Becker, A.; Stangarlin, J.R.; Franzener, G.; Lopes, M.C.; Schwan-Estrada, K.R.F. Control of Alternaria solani in tomato by Curcuma longa extracts and curcumin-II. In vivo evaluation. Fitopatol. Bras. 2006, 31, 401-404. [CrossRef]

15. Adams, R.P. Identification of Essential Oil Components by Gas Chromatography/Mass Spectrometry, 4th ed.; Allured Publishing Corporation: Carol Stream, IL, USA, 2007; 804p, ISBN 13-978-1932633214.

16. Santos, G.R.; Café-Filho, A.C.; Leão, F.F.; César, M.; Fernandes, L.E. Disease progress and crop losses due to watermelon gummy stem blight. Hortic. Bras. 2005, 23, 228-232. [CrossRef]

17. Schneider, R.W.; Williams, R.J.; Siwclair, J.B. Cercospora leaf spot of cowpea: Model for estimating yield loss. Phytopathology 1976, 66, 384-388. [CrossRef]

18. Magalhães, P.C.; Silva, J.B.; Durães, F.O.M. Toxicity of herbicides post emergents at maize crop initial phase. Planta Daninha 2000, 18. [CrossRef]

19. Sarmento-Brum, R.B.C.; Santos, G.R.; Castro, H.G.; Gonçalves, C.G.; Júnior, A.F.C.; Nascimento, I.R. Effect of essential oils of medicinal plants on the anthracnose of sorghum. Biosci. J. 2013, 29, 1549-1557. Available online: http:/ / www.seer.ufu.br/index.php/biosciencejournal/article/view/15229 (accessed on 14 November 2015).

20. Guimarães, L.G.L.; Cardoso, M.G.; Souza, P.E.; Andrade, J.; Vieira, S.S. Antioxidant and fungitoxic activities of the lemongrass essential oil and citral. Rev. Ciênc. Agron. 2011, 42, 464-472. [CrossRef]

21. Souza Júnior, I.T.S.; Sales, N.L.P.; Martins, E.R. Fungitoxic effect of concentrations of essential oils on Colletotrichum gloeosporioides, isolated from the passion fruit. Biotemas 2009, 22, 77-83. [CrossRef]

22. Pinto, D.A.; Mantovani, E.C.; Melo, E.D.C.; Sediyama, G.C.; Vieira, G.H.S. Growth production and essential oil quality of lemongrass (Cymbopogon citratus) under different irrigation depths. Rev. Bras. Plantas Med. 2014, 16, 54-61. [CrossRef]

23. Gonçalves, A.H.; Pereira, A.S.; Santos, G.R.; Guimarães, L.G.L. Fungitoxicity in vitro of essential oils from Lippia sidoides Cham., Cymbopogon citratus (D.C.) Stapf. and their major constituents in the control of Rhizoctonia solani and Sclerotium rolfsii. Rev. Bras. Planta Med. 2015, 17, 1007-1015. [CrossRef] 
24. Aquino, C.F.; Sales, N.L.P.; Soares, E.P.S.; Martins, E.R.; Costa, C.A. Chemical composition and in vitro activity of three essential oils on Colletotrichum gloeosporioides from passion fruit. Rev. Bras. Planta Med. 2014, 16, 329-336. [CrossRef]

25. Santos, G.R.; Brum, R.B.C.S.; Castro, H.G.; Gonçalves, C.G.; Fidelis, R.R. Effect of essential oils of medicinal plants on leaf blotch in Tanzania grass. Rev. Ciênc. Agron. 2013, 44, 587-593. [CrossRef] 